\title{
The Relationship Between Merchants
}

\section{Knowledge and Attitude Toward the Obedience of Mask Use in Preventing Covid-19 (At Religious Tourism of Sunan Bonang Tuban)}

\author{
Aulia Baidhotunnisa ${ }^{1}$, Titik Sumiatin ${ }^{1}$, Sư udi ${ }^{1}$ \\ ${ }^{1}$ Departement of Nursing Poltekkes Kemenkes, Surabaya \\ Corresponding author: Aulia Baidhotunnisa (e-mail: auliabaidhotunnisa07@gmail.com).
}

\begin{abstract}
The COVID-19 outbreak began in December 2019. In preventing its transmission, society across the world agrees to use a mask for their safety. However, today, people, primarily some merchants who sell their stuff around the tourism places, still do not obey the regulation to wear a mask. Hence, this study aims to know the relationship between merchant knowledge and attitude toward the obedience of using a mask in preventing the COVID-19 transmission at the religious tourism of Sunan Bonang Tuban. The research design used in this study is the correlation analysis that uses a cross-sectional approach. Moreover, the sampling technique used in this study is Simple Random Sampling with 105 populations and 83 samples of merchants. The data technique used in this study is a questionnaire. Then, the researcher analyzes the questionnaire with a percentage and does a crosstab by using the Spearman Rank Correlation test. The finding of this study presents that most of the merchants at religious tourism of Sunan Bonang Tuban have good knowledge in preventing COVID-19 transmission. It is about Forty-nine people $(59,0 \%)$. Then, fifty people $(60,2 \%)$ have a positive attitude. Moreover, the finding presents that almost half of the merchants, thirty-five people $(42,2 \%)$, obey the regulation to wear the mask. The result of Spearman Rank Correlation test is $\alpha$ $=0.00<0.05$. This result shows the relationship between knowledge and obedience in using the mask. The result of the test is $\alpha=0.00<0.001$ shows there is a relationship between the attitude and the obedience in using the mask of merchants to prevent COVID-19 at the religious tourism of Sunan Bonang Tuban. The knowledge and attitude of merchants influence their obedience in using the mask. It means that the more increased merchants' knowledge and attitude, the more increased merchant obedience. In increasing and encouraging other merchants' knowledge and attitude, the government must have a good strategy. One of the appropriate strategies is doing counseling of using a mask to prevent COVID-19 transmission.
\end{abstract}

INDEX TERMS Knowledge, Attitude, The Obedience of Using Mask

\section{INTRODUCTION}

The occurrence of the COVID-19 outbreak in the world began in December 2019. The COVID-19 outbreak includes a new type of virus in humans that has never been identified before (Ministry of Health RI, 2020). The mutation process of the SARS-CoV virus becomes very infectious which causes the COVID-19 outbreak, patients who are in the incubation period and are falsely detected can transmit the virus [2]. The COVID-19 virus is spread mainly through droplets of saliva or fluids from the nose when an infected person coughs or sneezes (WHO, 2020). [1] The Indonesian government declared a disaster emergency status at the end of last February by issuing rules and recommendations for health protocols that the public must obey. One of the regulations issued by the Government is the Regulation of the Minister of Health of the Republic of Indonesia Number 9 of 2020 concerning Guidelines for Large-Scale Social Restrictions in the Context of Accelerating the Handling of Corona Virus Disease 2019 (Covid-19). Distance restrictions, also known as physical 
distancing, are echoed in almost all parts of the country. as one of the steps taken to reduce the spread of this virus [2].

One of the efforts to prevent transmission that has been agreed upon by the world is the use of masks by the entire community. The use of cloth masks for the general public has been recommended by the Centers for Disease Control and Prevention, namely the Centers for Disease Control (CDC) and the World Health Organization (WHO), Indonesia is one of the countries that follow the recommendations of the CDC and WHO [3].

Before the pandemic at Religious Tourism of Sunan Bonang in Tuban district was one of the destination's tourism in Tuban district, until now in the midst of a pandemic situation, the surge in activity persists can be felt on the weekends. Traveler which came almost dominated by children and toddlers, this is because street vendors in this area offer a variety of rides for child play. Through on-site observations, found many tourists who do not do it social distancing movement, not using masks as the first step of self-protection for the spread of Covid-19 as echoed by the Government. WHO has concluded that wearing a mask and keeping your distance reduce the risk of transmitting Covid-19 by up to $85 \%$ (WHO, 2020). Until now, the Religious Tourism of the Sunan Bonang area in Tuban district is still filled with social interactions between humans and street vendors without complying with the protocol health that has been determined by the Government. In this kind of situation, it's possible that this location can be one of the clusters the spread of Covid-19 in Tuban Regency [4].

On July 20, 2020, the Regent of Tuban signed a circular (SE) regarding Adaptation of New Habits (IMR) in the tourism sector, namely managers of tourist destinations are allowed to operate by limiting visitors to a maximum of 50\% of the capacity of tourism objects. This is used by traders to seek sustenance by selling around tourist objects in the hope of fulfilling their economy during the pandemic. Tourists spend the money they bring to eat, drink, buy souvenirs and so on which provides a lot of input or foreign exchange for the region or the local community. However, it is feared that there will be the addition of new clusters in the tourism object environment, especially for traders. According to circular letter number HK.02.01/MENKES//335/2020 regarding protocols for preventing the transmission of COVID-19 in the service and trade sector workplaces (public areas) in supporting business continuity,[4]. Until now, there are still people who do not comply with applicable health protocols, such as not implementing proper mask-wearing behavior, especially to traders who sell around tourist attractions, so that the number of positive COVID-19 cases in Tuban is still increasing. [5]

From TABLE 1, it can be seen that from October to December there was an increase in COVID-19 cases in Indonesia by $55.2 \%$, equivalent to 333,110 cases with 743,198 confirmed positive, 611,097 recovered and 22,138 died. Meanwhile, in Tuban Regency, there was an increase in COVID-19 cases by $35.6 \%$, equivalent to 1152 cases with a total of 1790 positive status, 1160 declared cured and 190 died. Tuban Regency is a district in East Java that was once designated as a red zone area. One of the distributions of the corona virus in this district came from a cluster of traders, including 3 traders from the Tuban Unloading market and 1 trader from Tuban CFDs who had been confirmed positive for COVID-19 (Sudarsono, 2020; Ochiem, 2020).

$$
\text { TABLE } 1
$$

Data on Confirmed Increase, Recovered and Died Due to COVID-19 in Indonesia, East Java, and Tuban Regency.

\begin{tabular}{lllll}
\hline Month & & National & East Java & $\begin{array}{l}\text { Regency. } \\
\text { Tuban }\end{array}$ \\
\hline \multirow{3}{*}{ October } & Positive & 410.088 & 52,465 & 638 \\
& Healed & 337,801 & 46,378 & 505 \\
& Die & 13,869 & 3.768 & 78 \\
\hline \multirow{3}{*}{ November } & Positive & 538,883 & 61,883 & 786 \\
& Healed & 450,518 & 54,490 & 614 \\
& Die & 16,945 & 4.407 & 91 \\
\hline \multirow{3}{*}{ December } & Positive & 743,198 & 84.152 & 1790 \\
& Healed & 611.097 & 72.135 & 1160 \\
& Die & 22,138 & 5.827 & 190 \\
\hline
\end{tabular}

Source : (National COVID-19 Task Force and East Java [6]

The transmission of the COVID-19 virus can spread and has a high transmission power due to the presence of droplets containing the virus or airflow (aerosol), which is very important to control the source of infection during a pandemic (Atmojo, 2020). Meanwhile, during a pandemic like this, traders who seek sustenance at tourist attractions must protect themselves from the transmission of the corona virus by complying with health protocols, one of which is applying proper mask wearing behavior. Shereen et al., (2020, in Atmojo, 2020) said that the use of masks has become an obligation that must be applied to all people when interacting. Based on a preliminary preliminary survey on October 29 , 2020 conducted on 5 traders at Sunan Bonang Tuban Religious tourism, it was found that 2 out of 5 traders wore masks properly at work, 1 trader wore a mask as a neck necklace and 2 traders did not wear a mask. Adherence to the proper use of masks is expected to reduce the risk of the spread of the corona virus and reduce the transmission rate of the COVID-19 disease. Until now, there are still traders who do not comply with the behavior of wearing masks according to health protocols. This can happen due to several factors that can affect community compliance. Community compliance is influenced by five factors, namely age, education, knowledge, attitudes and motivation. People who have high knowledge can be encouraged to obey in following the health protocols that have been set by the government (Novi Afrianti; Cut Rahmiati, 2021). According to research by Webster, et al (2020), the increasing positive attitude of the community in complying with the regulations for handling and preventing COVID-19 is due to trust.

Therefore, the government must have the right strategy to be able to disseminate information related to COVID-19 and 
its prevention so that it can increase knowledge and can encourage traders to implement proper mask wearing behavior, especially for people who are considered at risk and have low knowledge about this disease.

\section{METHODS}

The research used correlation analytic with cross sectional approach. The sampling technique used is Simple Random Sampling with a population of 105 traders and 83 samples. The data technique used was a questionnaire sheet which was then analyzed by percentage, cross tabulated and analyzed using the Spearman Rank Correlation test.

\section{RESULT}

A. TRADER'S KNOWLEDGE ABOUT THE USE OF MASKS IN PREVENTING COVID-19 AT RELIGIOUS TOURISM SUNAN BONANG TUBAN.

Based on TABLE 2, it is known that the knowledge of traders about the use of masks in the prevention of COVID-19 at Sunan Bonang Tuban Religious Tourism, most of them have good knowledge, namely 49 people $(59.0 \%)$.

TABLE 2

Distribution of Trader's Knowledge About the Use of Masks in Preventing COVID-19 at Religious Tourism Sunan Bonang Tuban.

\begin{tabular}{lcc}
\hline Knowledge & Frequency (f) & Percentage (\%) \\
\hline Well & 49 & $59.0 \%$ \\
Enough & 29 & $34.9 \%$ \\
Not enough & 5 & $6.0 \%$ \\
\hline Total & $\mathbf{8 3}$ & $\mathbf{1 0 0}$ \\
\hline
\end{tabular}

B. TRADERS' ATTITUDES ABOUT THE USE OF MASKS IN PREVENTING COVID-19 AT RELIGIOUS TOURISM SUNAN BONANG TUBAN.

Based on TABLE 3, it is known that the attitude of traders regarding the use of masks in preventing COVID-19 at Sunan Bonang Tuban Religious Tourism, most of them have a positive attitude, namely 50 people $(60.2 \%)$

$$
\text { TABLE } 3
$$

Distribution of Traders' Attitudes About the Use of Masks in Preventing COVID-19 at Religious Tourism Sunan Bonang Tuban

\begin{tabular}{lcc}
\hline Attitude & Frequency (f) & Percentage (\%) \\
\hline Positive & 50 & $60.2 \%$ \\
Negative & 33 & $39.8 \%$ \\
\hline Total & $\mathbf{8 3}$ & $\mathbf{1 0 0}$ \\
\hline
\end{tabular}

\section{MERCHANT COMPLIANCE REGARDING THE USE OF MASKS IN PREVENTION COVID-19 IN RELIGIOUS TOURISM SUNAN BONANG TUBAN.}

Based on TABLE 4, it is known that the compliance of traders regarding the use of masks in the prevention of COVID-19 at Sunan Bonang Tuban Religious Tourism, almost half of them have moderate compliance, namely 35 people (42.2\%) and a small portion still has low compliance, namely 16 people $(19.3$ $\%)$.

TABLE 4

Distribution of Merchant Compliance Regarding the Use of Masks in Preventing COVID-19 at Religious Tourism Sunan Bonang Tuban.

\begin{tabular}{lll} 
Obedience & Frequency (f) & Percentage (\%) \\
\hline Tall & 32 & $38.6 \%$ \\
Currently & 35 & $42.2 \%$ \\
Low & 16 & $19.3 \%$ \\
\hline Total & $\mathbf{8 3}$ & $\mathbf{1 0 0}$ \\
\hline
\end{tabular}

\section{KNOWLEDGE ANALYSIS WITH MERCHANT COMPLIANCE ABOUT USAGE MASK IN PREVENTING COVID-19 AT SUNAN BONANG RELIGIOUS TOURISM TUBAN.}

Based on TABLE 5, it is known that out of 83 traders, most of them, namely 27 traders $(55.1 \%)$ with good knowledge have high compliance.

Based on the results of the Spearman Rank Correlation test using SPSS version 16, it was found that $=0.00$ with $<0.05$ indicating that there is a relationship between knowledge and compliance with the use of masks by traders in preventing COVID-19 at Religious Tourism Sunan Bonang Tuban. And the correlation coefficient value is $0.377^{*} *$, which means the correlation value is low and in the same direction.

TABLE 5

Cross-tabulation of the Relationship between Knowledge and Compliance with the Use of Masks by Traders in Preventing COVID-19 at Religious Tourism Sunan Bonang Tuban.

\begin{tabular}{|c|c|c|c|c|c|c|c|c|}
\hline \multirow{3}{*}{ Knowledge } & \multicolumn{6}{|c|}{ Obedience } & \multirow{2}{*}{\multicolumn{2}{|c|}{$\begin{array}{l}\text { Total } \\
\text { number }\end{array}$}} \\
\hline & \multicolumn{2}{|c|}{ Tall } & \multicolumn{2}{|c|}{ Currently } & \multicolumn{2}{|c|}{ Low } & & \\
\hline & $\mathrm{N}$ & $\%$ & $\mathrm{~N}$ & $\%$ & $\mathrm{~N}$ & $\%$ & $\mathrm{~N}$ & $\%$ \\
\hline Well & 27 & 55.1 & 14 & 28.6 & 8 & $16.3 \%$ & 49 & 100 \\
\hline Enough & 5 & 17.2 & 20 & 69.0 & 4 & $13.8 \%$ & 29 & 100 \\
\hline Not enough & 0 & 0 & 1 & 20.0 & 4 & $80.0 \%$ & 5 & 100 \\
\hline Amount & 32 & 38.6 & 35 & 42.2 & 16 & $19.2 \%$ & 83 & 100 \\
\hline
\end{tabular}

Spearman Rank Correlation Test $=0.377 * *$ Significant $=0.00, \mathrm{~N}=83$

\section{E. ANALYSIS OF ATTITUDES WITH MERCHANT COMPLIANCE REGARDING THE USE OF MASKS IN PREVENTING COVID-19 AT SUNAN BONANG RELIGIOUS TOURISM TUBAN.}


TABLE 6

Cross-tabulation of the Relationship between Attitudes and Compliance with the Use of Masks on Traders in Preventing COVID-19 at Religious Tourism Sunan Bonang Tuban.

\begin{tabular}{|c|c|c|c|c|c|c|c|c|}
\hline \multirow{3}{*}{ Attitude } & \multicolumn{6}{|c|}{ Obedience } & \multirow{2}{*}{\multicolumn{2}{|c|}{$\begin{array}{c}\text { Total } \\
\text { number }\end{array}$}} \\
\hline & \multicolumn{2}{|c|}{ Tall } & \multicolumn{2}{|c|}{ Currently } & \multicolumn{2}{|c|}{ Low } & & \\
\hline & $\mathrm{N}$ & $\%$ & $\mathrm{~N}$ & $\%$ & $\mathrm{~N}$ & $\%$ & $\mathrm{~N}$ & $\%$ \\
\hline Positive & 24 & 48.0 & 23 & 46.0 & 3 & 6.0 & 50 & 100 \\
\hline Negative & 8 & 24.2 & 12 & 36.4 & 13 & 39.4 & 33 & 100 \\
\hline Amount & & & & & & & 83 & 100 \\
\hline
\end{tabular}

Spearman Rank Correlation Test $=0.363^{*} *$ Significant $=0.001$

$\mathrm{N}=83$

Based on TABLE 6, it is known that from a total of 83 traders, a positive attitude that has high compliance is 24 traders $(48.0 \%)$

From the results of the Spearman Rank Correlation test using SPSS version 16, it was found that $=0.01$ with $<0.05$, which means that there is a relationship between attitude and compliance with the use of masks by traders in preventing COVID-19 at Sunan Bonang Tuban Religious Tourism. And the correlation coefficient value is $0.363^{* *}$, which means the correlation value is low and in the same direction.

\section{DISCUSSION}

\section{A. TRADERS KNOWLEDGE ABOUT THE USE OF MASKS IN PREVENTING COVID-19 AT RELIGIOUS TOURISM SUNAN BONANG TUBAN}

Based on TABLE 1, it is known that the knowledge of traders about the use of masks in the prevention of COVID-19 at Sunan Bonang Tuban Religious Tourism, most of them have good knowledge, namely 49 people $(59.0 \%)$.

According to Wawan and M. Dewi (2011) internal factors which include education, occupation, and age and external factors which include environmental and socio-cultural factors are factors that affect one's knowledge. The results of the cross tabulation in this study showed that as many as 24 traders (28.9\%) in the early adult age group (18-40 years) had good knowledge about the use of masks. This research is not in line with Harlock's theory, if one is old enough or the age of a person increases, the level of maturity and strength of a person will be more mature in thinking and working.

Knowledge itself is influenced by a person's formal education. Knowledge is very closely related to education, where it is expected that if someone with a high education then that person will continue to be broad in knowledge (Wawan \& Dewi, 2011). The results of the cross tabulation in this study showed that as many as 35 traders $(42.2 \%)$ had a formal education with the latest high school education (SLTA) having good knowledge about the use of masks. Education can affect a person, including a person's behavior regarding the pattern of life, especially in motivating attitudes to participate in development. [7]

The knowledge of traders about the use of masks in preventing COVID-19 at Sunan Bonang Tuban Religious
Tourism is influenced by the early adult age group (18-40 years) and the last formal education factor, namely Senior High School (SLTA).

\section{B. TRADERS' ATTITUDES ABOUT THE USE OF MASKS IN PREVENTING COVID-19 AT RELIGIOUS TOURISM SUNAN BONANG TUBAN}

Based on TABLE 3, it is known that the attitude of traders regarding the use of masks in preventing COVID-19 at Sunan Bonang Tuban Religious Tourism, most of them have a positive attitude, namely 50 people $(60.2 \%)$.

According to Notoadmojo (2014, in Dian Adriani \& Neneng Kurwiyah 2019) says if attitude is a response or reaction that is still closed from a person to a stimulus or object followed by certain feelings.

According to Heri Purwanto (1998, in Wawan, 2011) says if the attitude of a person can be divided into two, namely, a positive attitude and a negative attitude. Positive attitudes tend to approach, like, and expect certain objects, whereas negative attitudes tend to stay away from, avoid, hate, and dislike certain objects. According to Wawan (2011) the factors that influence attitudes towards the object of attitude include individual experiences, the influence of other people who are considered important, the influence of culture, mass media, educational institutions and religious institutions as well as emotional factors. [8]

The attitude of traders regarding the use of masks in preventing COVID-19 at Sunan Bonang Tuban Religious Tourism is mostly positive because traders know the importance of using masks in preventing COVID-19 which aims to protect the nose and mouth from the spread of the corona virus.

\section{MERCHANT COMPLIANCE REGARDING THE USE OF MASKS IN PREVENTING COVID-19 AT RELIGIOUS TOURISM SUNAN BONANG TUBAN}

Based on TABLE 4, it is known that the compliance of traders regarding the use of masks in the prevention of COVID-19 at Sunan Bonang Tuban Religious Tourism, almost half of them have moderate compliance, namely 35 people $(42.2 \%)$ and a small portion still has low compliance, namely 16 people $(19.3$ $\%)$.

This study is in line with previous research which showed that 46 respondents $(74.19 \%)$ were obedient in using masks and the remaining 16 respondents $(25.81 \%)$ were not obedient in using masks. According to research by Novi Afrianti \& Cut Rahmiati (2020) the factors that influence people's compliance with health protocols are age, education, knowledge, attitudes and motivation. According to circular letter number HK.02.01/MENKES//335/2020 concerning protocols for preventing the transmission of COVID-19 in the service and trade sector workplaces (public areas) in supporting business continuity, requiring workers and visitors to protect themselves by wearing masks, they can reduce the risk of contracting the virus. [9] 
The results of this study still found low compliance with traders. Low compliance with traders regarding the use of masks in the prevention of COVID-19 at Sunan Bonang Tuban Religious Tourism is influenced by knowledge and attitude factors.

\section{KNOWLEDGE ANALYSIS WITH TRADER COMPLIANCE ABOUT THE USE OF MASKS IN PREVENTING COVID-19 AT RELIGIOUS TOURISM SUNAN BONANG TUBAN}

Based on TABLE 5, it is known that most (55.1\%) traders with good knowledge have high compliance. Based on the results of the Spearman Rank Correlation test using SPSS version 16, it was found that $=0.00$ with $<0.05$ indicating that there is a relationship between knowledge and compliance with the use of masks by traders.

The results of this study are in line with research conducted by Devi Pramita Sari \& Nabila Sholihah 'Atiqoh (2020) where the results of the study show that there is a relationship between public knowledge and adherence to the use of masks of $=0.004$ with $<0.05$.

Knowledge is one of the important things to consider in the context of handling, especially in avoiding transmission and suppressing the spread of the virus (Law, Leung, \& Xu, 2020). The knowledge possessed affects a person in determining and making decisions on a case experienced (Purnamasari, Ika: Raharyani, 2020). This is supported by Ahmadi (2013) who said that if someone who has knowledge of information will be able to determine and make decisions in dealing with a problem, or in other words, people who have knowledge about COVID-19 will be able to determine how they are obliged to do so. behavior in dealing with the disease. [10]

From the description above, it can be concluded that knowledge is very influential in the compliance of traders regarding the use of masks in preventing COVID-19 at Sunan Bonang Tuban Religious Tourism. [11] Where traders who have good knowledge about the use of masks in the prevention of COVID-19, the level of compliance in the use of masks in the prevention of COVID-19 is also good. However, as it is known that not entirely the factors that influence a person's compliance with the use of masks in preventing COVID-19 are knowledge, but there are also other factors that support a person's compliance, such as age, education, attitude and motivation. However, a person's obedience is strongly influenced by knowledge. The better a person's level of knowledge, the better the level of compliance. [12]

\section{E. ANALYSIS OF ATTITUDES WITH MERCHANT COMPLIANCE REGARDING THE USE OF MASKS IN PREVENTING COVID-19 AT RELIGIOUS TOURISM SUNAN BONANG TUBAN}

Based on TABLE 6, it is known that the positive attitude that has high compliance is $24(48.0 \%)$. From the results of the Spearman Rank Correlation test using SPSS version 16, it was found that $=0.01$ with $<0.05$, which means that there is a relationship between attitude and compliance with the use of masks by traders in preventing COVID-19 at Sunan Bonang Tuban Religious Tourism.

The results of this study are in line with research conducted by Dian Andriani \& Neneng Kurwiyah (2019) where the results of his research show that there is a relationship between attitudes towards mask compliance of $=0.003$ with $<0.05$.

Attitude is a person's opinion about a certain condition or situation and is influenced by several factors. Experience has an important role in the formation of attitudes. [13] Not only experience, attitude formation is also influenced by trust where a person will have an obedient attitude towards policies if there is trust if the policy is effective in reducing the spread of COVID-19. This is in line with research by Webster, et al (2020) which states that trust in government decisions is one of the factors that increase the positive attitude of the community in complying with COVID-19 handling and prevention regulations. [14]

From the description above, it can be concluded that attitude is very influential in the compliance of traders regarding the use of masks in preventing COVID-19 at Sunan Bonang Tuban Religious Tourism. Where traders have a positive attitude about wearing masks in preventing COVID-19, the level of compliance in wearing masks in preventing COVID19 is also good. However, as it is known that not entirely the factors that influence a person's compliance with the use of masks in preventing COVID-19 are attitudes, but there are also other factors that support a person's compliance, such as age, education, knowledge and motivation. [15] However, a person's obedience is strongly influenced by attitude. The increase in a person's positive nature, the obedience will also increase.

\section{CONCLUSION}

The purpose of this study to know the relationship between merchant knowledge and attitude toward the obedience of using a mask in preventing the COVID-19 transmission at the religious tourism of Sunan Bonang Tuban. Most (59.0\%) traders at Sunan Bonang Tuban Religious Tourism have good knowledge about the use of masks in the prevention of COVID-19.

There is a relationship between knowledgewith the compliance of traders regarding the use of masks in the prevention of COVID-19 at Sunan Bonang Tuban Religious Tourism. There is a relationship between attitudewith the compliance of traders regarding the use of masks in the prevention of COVID-19 at Sunan Bonang Tuban Religious Tourism.

For future research, it is recommended to study the effect of health education on changes in knowledge and attitudes of roadside traders regarding limiting the spread of COVID-19 infection. 


\section{REFERENCES}

[1] W. H. Organization,

https://www.who.int/dg/speeches/detail/who-director-generals-opening-re...," World Health Organization., 11 March 2020 March $2020 . \quad$ [Online]. Available: https://pubmed.ncbi.nlm.nih.gov/34125839/. [Accessed 15 Desember 2021].

[2] M.-C. Kim, "Impact of social distancing on the spread of common respiratory viruses during the coronavirus disease outbreak," PubMed, vol. 16, no. 6, 2021.

[3] H. Thakur, "A Strengths, Weaknesses, Opportunities, and Threats Analysis of Public Health in India in the Context of COVID-19 Pandemic," Indian Journal Community Medicine, vol. 46, no. 1, pp. 1-3, 2021

[4] R. J. Coker, "Emerging infectious diseases in southeast Asia: regional challenges to control," Elsevier Public Health Emergency Collection, vol. 377, pp. 599-609, 2021.

[5] D. Budiman, "A SWOT Analysis of Indonesia's COVID-19 Pandemic Response Strategy," International Journal of Advanced Health Science and Technology, vol. 1, no. 2, pp. 50-52, 2021

[6] N. C.-1. T. F. a. E. Java, "https://tubankab.go.id/page/information-about-virus-coronacovid-19," [Online]. Available: https://covid19.go.id/. [Accessed 31 Desember 2020].

[7] "Motivations for Social Distancing and App Use as Complementary Measures to Combat the COVID-19 Pandemic: Quantitative Survey Study," JOURNAL OF MEDICAL INTERNET RESEARCH, vol. 22, no. 8, pp. 1-13, 2020

[8] J. T. Atmojo, "Penggunaan Masker Dalam Pencegahan Dan Penanganan Covid-19: Rasionalitas, Efektivitas, Dan Isu Terkini.," Journal of Health Research, vol. 3, no. 2, pp. 84-95, 2020.

[9] Achuta Guddati, "Protection of Health Care Professionals During an Epidemic: Medical, Ethical, and Legal Ramifications," INTERACTIVE JOURNAL OF MEDICAL RESEARCH, vol. 9, no. 3, pp. 1-3, 2020.

[10] S. F. Rizqah, "Hubungan Perilaku Masyarakat Dengan Kepatuhan Penggunaan Masker Untuk Memutus Rantai Penularan Covid-19 Di Kelurahan Bontoa Maros," Muslim Community Health, vol. 2, no. 3, pp. 165-175, 2021.

[11] Y. Astuti, "Hubungan Tingkat Pengetahuan Dan Sikap Perawat Dengan Tingkat Kepatuhan Penggunaan Alat Pelindung Diri Di Ruang Icu, Igd Dan Irna Imam Bonjol Rsud "Kanjuruhan" Kepanjen Kabupaten Malang," Jurnal IImiah Keperawatan, vol. 3, no. 3, p. 663-669, 2018.

[12] M. Mujiburrahman, "Hubungan Pengetahuan dengan Perilaku Pencegahan Covid-19 di Masyarakat," Jurnal Keperawatan Terpadu, vol. 2, no. 2, pp. 130-140, 2020.

[13] M. Z. Ferdous, "Knowledge, attitude, and practice regarding COVID-19 outbreak in Bangladesh: An online-based crosssectional study," PLOS ONE, vol. 15, no. 10, pp. 1-17, 2020.

[14] S. D. Baral, "The Relationship Between the Global Burden of Influenza From 2017 to 2019 and COVID-19: Descriptive Epidemiological Assessment," JMIR PUBLIC HEALTH AND SURVEILLANCE, vol. 7, no. 3, pp. 1-16, 2021.

[15] M. Saefi, "Survey data of COVID-19-related knowledge, attitude, and practices among indonesian undergraduate students," ScienceDirect, vol. 31, pp. 1-10, 2020. 